\title{
Chromosomal Comparisons among and within Populations of Simulium (Chirostilbia) pertinax (Diptera, Simuliidae)
}

\author{
Jairo Campos ${ }^{+}$, Carlos Fernando S Andrade, Shirlei M Recco-Pimentel*
}

Departamento de Zoologia *Departamento de Biologia Celular, Instituto de Biologia, Universidade Estadual de Campinas, 13084-971 Campinas, SP, Brasil

Chromosomal studies were carried on six larval populations of Simulium (Chirostilbia) pertinax from different locations in Brazil. Larvae were collected in the states of Paraná, Rio Grande do Sul, Rio de Janeiro and São Paulo. Polytene chromosome map comparisons within and among populations showed no differences in banding pattern, except for some limited polymorphism (secondary NOR and four band polymorphisms). There were no chromosomal variations associated with the resistance or susceptibility of the larvae to temephos. The chromosomal homosequentiality found among the six populations suggests that $\mathrm{S}$. pertinax may be a monomorphic species.

Key words: cytology - insecticide resistance - polytene chromosomes

The micromorphology of polytene chromosomes has provided many key traits for dipteran species characterization and phylogenetic investigations. The polytene chromosomes of simuliid populations have been analyzed for practical reasons such as the identification of species and cytotypes with vectorial capacity or to assess resistance or susceptibility to insecticides in order to improve control programs (Post 1986, Charalambous et al. 1995).

Despite the medical and socio-economic importance of some black fly species in Brazil, few cytological studies have been published (Charalambous et al. 1996, Campos et al. 1996, Hamada \& Adler 1999). The objective of the present study was to compare the banding patterns of larval polytene chromosomes of six Simulium (Chirostilbia) pertinax populations in the absence or presence of selection pressure caused by regular treatment with the larvicide temephos.

\section{MATERIALS AND METHODS}

Six geographically separated $S$. pertinax populations were studied, three of them along the southeastern coast of Brazil at Barra do Una $(n=42)$, Ilhabela $(n=69)$ (State of São Paulo) and Muriqui (State of Rio de Janeiro, $n=46$ ). The other three

\footnotetext{
This research was supported by M Brown Foundation, $\mathrm{CNPq}$ and Capes.

${ }^{+}$Corresponding author. Fax: +55-19-289.3124. E-mail: jairocag@unicamp.br; cfeandra@unicamp.br Received 15 May 2000

Accepted 18 September 2000
}

populations included were one from the State of São Paulo plateau (Morungaba, $\mathrm{n}=115$ ), one from the grasslands of the State of Paraná (Tibaji, $\mathrm{n}=$ 13) and one from the Serra Gaúcha (Nova Petrópolis, $n=14$ ) (Table). The waterways were characterized in terms of altitude, temperature and current velocity. The susceptibility (S) or resistance (R) of the populations to temephos was assessed in last instars larvae exposed to an operational discriminative concentration of $0.1 \mathrm{ppm}$ a.i. of temephos/10 min (Andrade \& Campos 1995).

Larvae for the chromosomal studies were collected from October 1993 to June 1996 and preserved in Carnoy fixative (75\% absolute ethanol:25\% glacial acetic acid). The fixative was change twice during the first hour and the larvae then stored at $4^{\circ} \mathrm{C}$. Slides were prepared by the Feulgen method as described by Charalambous et al. (1993), with a modification consisting of restaining with lactoacetic orcein. Polytene chromosome maps (Campos et al. 1996) were based on the standard nomenclature.

\section{RESULTS}

The breeding sites of the six populations differed more in the altitude than in water temperature and velocity. The susceptibility to the organophosphorous temephos differed among the populations, with the larvae from Muriqui, RJ and Barra do Una, SP, being susceptible (S) and those from Ilhabela and Morungaba, SP, being resistant (R). The assay of larvae from Tibaji, PR, was inconclusive and the status was assumed to be probably resistant (?R); the larvae from Nova Petrópolis, RS, were not assayed (?S/R).

Polytene chromosomes -A detailed description of the polytene chromosomes of this species has 
TABLE

Collection data for Simulium (Chirostilbia) pertinax larvae

\begin{tabular}{|c|c|c|c|c|c|c|}
\hline \multirow[t]{2}{*}{ Population } & \multirow{2}{*}{$\begin{array}{c}\text { Location } \\
\text { Altitude (m) }\end{array}$} & \multirow{2}{*}{$\begin{array}{l}\text { Date of } \\
\text { collection }\end{array}$} & \multicolumn{3}{|c|}{ No. of larvae analyzed } & \multirow[t]{2}{*}{ Total } \\
\hline & & & Female & Male & $?^{a}$ & \\
\hline \multirow[t]{8}{*}{$\begin{array}{l}\text { Morungaba, SP } \\
(\mathrm{n}=115)\end{array}$} & $\begin{array}{l}46^{\circ} 47^{\prime} \text { LW } \\
22^{\circ} 50^{\prime} \mathrm{LS}\end{array}$ & $10-25-93$ & & 3 & 3 & \\
\hline & $900 \mathrm{~m}$ & $12-9-93$ & 1 & & 3 & 4 \\
\hline & & $1-16-94$ & & 1 & & 1 \\
\hline & & $4-15-94$ & 13 & 14 & 21 & 48 \\
\hline & & $26-5-94$ & 13 & 21 & 2 & 36 \\
\hline & & 7-11-94 & 5 & 7 & 2 & 14 \\
\hline & & 7-19-94 & & & 1 & 1 \\
\hline & & 4-15-95 & 2 & 6 & & 8 \\
\hline \multirow{3}{*}{$\begin{array}{l}\text { Ilhabela, SP } \\
\text { (Canudos) } \\
\qquad(\mathrm{n}=59)\end{array}$} & $45^{\circ} 21^{\prime} \mathrm{LW}$ & $12-11-93$ & & 2 & 2 & 4 \\
\hline & $75 \mathrm{~m}$ & $1-6-94$ & 8 & 15 & 7 & 30 \\
\hline & & $1-27-94$ & 17 & 8 & & 25 \\
\hline \multirow{2}{*}{$\begin{array}{l}\text { Ilhabela, SP (south) } \\
\qquad(\mathrm{n}=10)\end{array}$} & $45^{\circ} 27^{\prime} \mathrm{LW}$ & $2-21-96$ & 5 & 5 & & 10 \\
\hline & $\begin{array}{c}23^{\circ} 55^{\prime} \mathrm{LS} \\
75 \mathrm{~m}\end{array}$ & & & & & \\
\hline \multirow{2}{*}{$\begin{array}{l}\text { Barra do Una, SP } \\
\qquad(\mathrm{n}=42)\end{array}$} & $45^{\circ} 46^{\prime} \mathrm{LW}$ & $2-24-96$ & 4 & 3 & & 7 \\
\hline & $10 \mathrm{~m}$ & $3-16-96$ & 19 & 16 & & 35 \\
\hline \multirow{3}{*}{$\begin{array}{l}\text { Muriqui, RJ } \\
\qquad(\mathrm{n}=46)\end{array}$} & $43^{\circ} 57^{\prime} \mathrm{LW}$ & $7-29-94$ & 14 & 29 & 3 & 46 \\
\hline & $22^{\circ} 56^{\prime} \mathrm{LS}$ & & & & & \\
\hline & $125 \mathrm{~m}$ & & & & & \\
\hline \multirow{3}{*}{$\begin{array}{l}\text { Tibaji, PR } \\
\qquad(\mathrm{n}=14)\end{array}$} & $50^{\circ} 22^{\prime} \mathrm{LW}$ & $6-8-96$ & 7 & 6 & 1 & 14 \\
\hline & $24^{\circ} 39^{\prime} \mathrm{LS}$ & & & & & \\
\hline & $100 \mathrm{mI}$ & & & & & \\
\hline \multirow{2}{*}{$\begin{array}{l}\text { Nova Petrópolis, RS } \\
\qquad(\mathrm{n}=13)\end{array}$} & $51^{\circ} 12^{\prime} \mathrm{LW}$ & $5-19-94$ & 2 & 7 & 4 & 13 \\
\hline & $\begin{array}{c}29^{\circ} 25^{\prime} \mathrm{LS} \\
580 \mathrm{~m}\end{array}$ & & & & & \\
\hline \multicolumn{3}{|l|}{ Total } & 110 & 140 & 49 & 299 \\
\hline
\end{tabular}

$a$ :undetermined sex; SP: São Paulo; RJ: Rio de Janeiro; PR: Paraná; RS: Rio Grande do Sul

been reported for the Morungaba population (Campos et al. 1996, Campos 1997). In the present study, these chromosome maps were compared with those of five other S. pertinax populations. No inversion polymorphisms were seen in the six populations examined $(\mathrm{N}=299)$. The only polymorphisms observed occurred in the Rio de Janeiro and Paraná populations. One of these polymorphisms corresponded to a secondary NOR located at the base of the IL arm, section 26A/B (Fig. 1), which was expressed between the first two groups of bands in this section. The expression of such an NOR in only one of the homologues suggests a heterozygous state, with a population frequency of 0.022 $(\mathrm{n}=46)$ and a total frequency of $0.0033(\mathrm{~N}=299)$. The other polymorphisms consisted of variations in four bands in one individual. These polymorphisms were located in section $34 \mathrm{C} 1$ of the IL arm and near the telomere in section $97 \mathrm{~B} 3,4 / \mathrm{C} 3$ of the IIIL arm (Fig. 2). These four heterobands had a population frequency of $0.077(\mathrm{n}=13)$ and a total frequency of $0.0033(\mathrm{~N}=299)$. It was observed in only one individual and only once in more than ten complements.

\section{DISCUSSION}

The broad geographical distribution of $S$. pertinax (Coscarón 1987) and its occurrence in clear, rapid waters of natural environments as well as in polluted, slow waters of modified environments (Castello Branco Jr \& Andrade 1992) suggest that this species has a strong ability to adapt to different environments. The six populations studied differed in their $\mathrm{S}$ or $\mathrm{R}$ to temephos and in the environments in which they were found. $S$. pertinax from Barra do Una (S), Ilhabela (R) and 


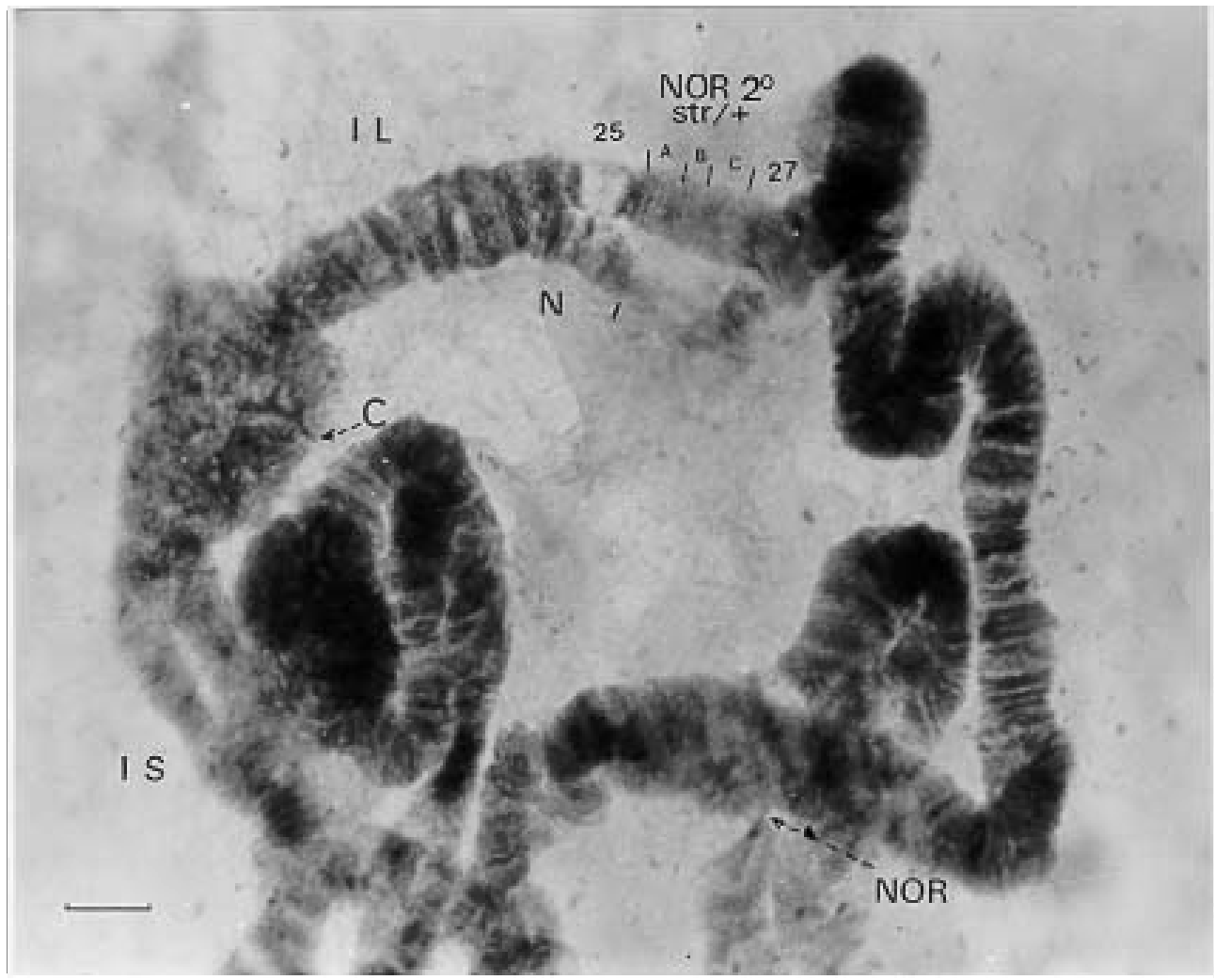

Fig. 1: polymorphism in the IL arm of Simulium (Chirostilbia) pertinax from Muriqui, RJ, 6th instar/male. Secondary nucleolar organizer region, NOR2nd str/+ (section 26A/B). C: centromere; N: nucleolus; NOR: nucleolar organizer region; str, standard chromosome; +: expressed chromosome. Bar $=8 \mu \mathrm{m}$
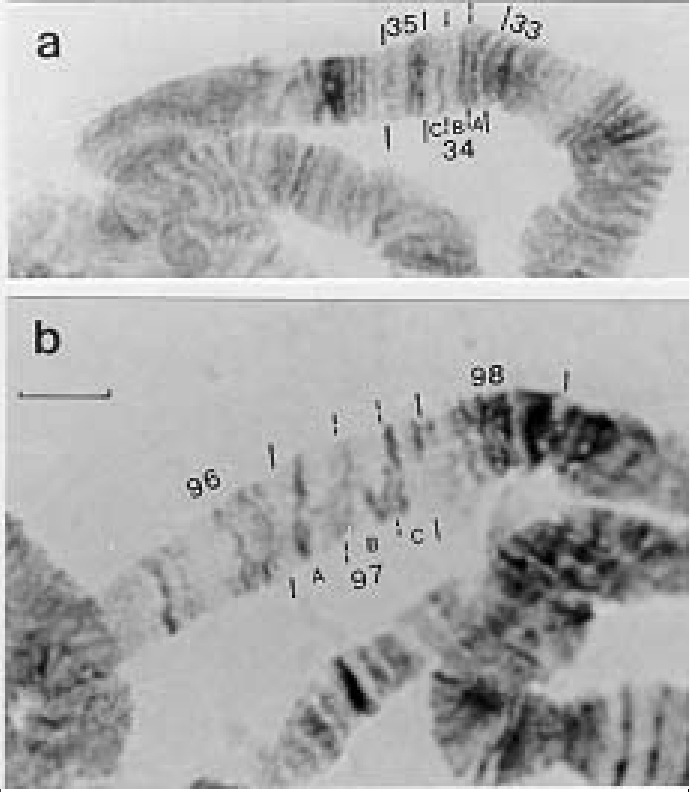

Fig. 2: band polymorphisms in the IL and IIIL arms of Simulium (Chirostilbia) pertinax from Tibaji, PR, 6th instar/male. a: heteroband in the IL arm, section 34C1; b: heterobands at the end of the IIIL arm, section 97B3,4/C3. Bar $=6 \mu \mathrm{m}$
Muriqui (S) were obtained from clear water streams in natural areas. The first two populations were controlled chemically until 1990 and since then have been under biological control with Bacillus thuringiensis israelensis. The populations from Nova Petrópolis (?S/R), Tibaji (?R) and Morungaba $(\mathrm{R})$, where collected from streams running through farms with intensive agriculture or animal husbandry. Only the population from the first site of the latter sites has been under biological control. However, all of them were probably exposed to chemicals in agricultural products since the population from Morungaba was $\mathrm{R}$ to temephos and all the larvae from Tibaji survived the discriminating concentration of this chemical. However, this result for the latter population was cosidered doubtful (?R) because the water temperature was $2^{\circ} \mathrm{C}$ below the ideal for this test (Back et al. 1979, Rodrigues \& Kaushik 1984 cited in Palmer et al. 1996).

Polytene chromosomes - The S. pertinax populations showed homogeneous and constant banding patterns for the polytene chromosomes. In contrast to some simuliid species (Rothfels \& 
Featherston 1981), asynaptic regions or regions without pairing between homologous chromosomes were infrequent in these populations. In the present study, analysis of 299 larvae demonstrated chromosomal homosequentiality among six populations from different sites, indicating that $S$. pertinax is a monotypic species, with little variation in its polytene chromosomes. Chromosomal homosequentiality may also occur among morphospecies (Bedo 1979a, Rothfels \& Featherston 1981, Henderson 1986), although this is an exception in Simuliidae (White 1977, Leonhardt \& Feraday 1989).

Chromosomal polymorphisms have been commonly recorded in the Simuliidae and showed geographical and/or temporal variability (Bedo 1979a, Henderson 1986). This was not the case for $S$. pertinax. Chromosomal polymorphisms have been helpful in characterizing other simuliid species since some species have many such polymorphisms whereas in others this phenomenon apparently does not occur at the same rate (Weber \& Grunewald 1989). Polymorphisms may appear in species inhabiting large areas as well as restricted sites (Duque et al. 1988, Conn et al. 1989, Hirai et al. 1994). Low frequencies of polymorphism may also be the consequence of reduced microhabitat diversity, but this does not apply to $S$. pertinax. Although the populations studied here were ecologically different, they showed no cytogenetic variations such as inversions.

The low chromosomal variability noted among simuliid populations may sometimes reflect the sample size (Bedo 1989). Heritability that does not differ significantly from zero, may also be the result of a small sample size rather than a lack of genetic diversity (Klein 1974, Storfer 1996). However, extensive polymorphism among populations has been detected in other dipteran species such as Chironomus tentans when samples of less than 50 individuals were analyzed. These populations showed similar banding patterns on their polytene chromosomes and could be differentiated only on the basis of inversion polymorphisms (Kiknadze et al. 1996). A tendency to monomorphism is often found in isolated populations (Carson 1959, Heed \& Russell 1971, Rothfels \& Featherston $1981)$ but $S$. pertinax populations are not isolated. The use of insecticides during more than two decades may have contributed to the homogeneity of these populations by reducing their chromosomal variability. Accordingly, monomorphism for one esterase (EST6) in Aedes aegypti populations was suggested to have resulted from the systematic application of insecticides (Dinardo-Miranda 1994) and reduced genetic variation was also found for genes closely linked to the organophosphate tar- get locus EST-4 in chromosome 1 of this same species (Yan et al. 1998).

The reduced chromosomal variation within and among the populations studied agreed with the findings of Hirai et al. (1994) for species of the $S$. ochraceum complex and with some allozymes studies of black fly populations (Feraday \& Leonhardth 1989). Highly conserved areas occur in the chromosomes of some simuliid species such as in the IIIS arm of Simulium species (Rothfels 1979, Procunier 1989) or chromosomes I and III of Ectemnaspis species (Campos \& Muñoz de Hoyos 1990). Since the absence of conspicuous chromosomal polymorphism is not necessarily conclusive evidence of reduced genetic variability among these populations, molecular studies could help to resolve this uncertainty. The polymorphism in nucleolar expression (NOR 2nd) seen in this study has been observed in other species (Bedo 1977, 1979b, Leonhardt 1985). De novo variations such as the intraindividual band polymorphisms observed here have also been recorded sporadically (Rothfels 1980).

\section{ACKNOWLEDGMENTS}

To Dr Sixto Coscarón for species identification.

\section{REFERENCES}

Andrade CFS, Campos J 1995. Efetividade de Bactivec, a base de Bacillus thuringiensis $\mathrm{H}-14$ no controle de Simulium pertinax (Diptera, Simuliidae). Rev Patol Trop 24: 275-281.

Back C, Lanoutte JG, Aubin A 1979. Preliminary tests on the use of temephos for the control of the black flies (Diptera: Simuliidae) in northern Quebec. Mosq News 39: 762-767.

Bedo DG 1977. Cytogenetics and evolution of Simulium ornatipes Skuse (Diptera: Simuliidae) I. Sibling speciation. Chromosoma 64: 37-65.

Bedo DG 1979a. Cytogenetics and evolution of Simulium ornatipes Skuse (Diptera: Simuliidae). II. Temporal variation in chromosomal polymorphisms and homosequential sibling species. Evolution 33: 296 308.

Bedo DG 1979b. Band and nucleolar polymorphisms in polytene chromosomes of Simulium ornatipes. Cytobios 21: 113-133.

Bedo DG 1989. A cytological study of Simulium ruficorne (Diptera: Simuliidae) and its relationship to the $S$. ornatipes species complex. Genome 32: 570579.

Campos J 1997. Estudos Cromossômicos em Populações de Simulium (Chirostilbia) pertinax (Diptera, Simuliidae), MSc Thesis, Universidade Estadual de Campinas, Campinas, 86 pp.

Campos J, Muñoz de Hoyos P 1990. Los cromosomas politénicos de Simulium furcillatum (Diptera: Simuliidae) Chisacá, Cundinamarca, Colombia. Rev Acad Colomb Cienc 17: 715-723. 
Campos J, Recco-Pimentel SM, Andrade CFS 1996. Polytene chromosome analysis of a population of Simulium pertinax (Diptera: Simuliidae). Rev Bras Genet 19: 47-52.

Carson HL 1959. Genetic conditions which promote or retard the formation of the species. Quant Biol 24: 87-105.

Castello Branco Jr A, Andrade CFS 1992. Susceptibility of Simulium (Chirostilbia) pertinax Kollard, 1832 (Culicomorpha, Simuliidae) to Bacillus thuringiensis var. israelensis in an atypical breeding habitat. Mem Inst Oswaldo Cruz 87: 317-318.

Charalambous M, Ready PD, Shelley AJ, Arzube M, Lowry CA 1993. Cytological and isoenzyme analysis of the Bucay and Quevedo cytotypes of the onchocerciasis vector Simulium exiguum (Diptera: Simuliidae) in Ecuador. Mem Inst Oswaldo Cruz 88: 39-48.

Charalambous M, Shelley AJ, dos Santos Grácio AJ, Raybould JN 1995. Cytogenetical analysis of the Simulium damnosum complex (Diptera: Simuliidae) in Guinea Bissau. Med Vet Entomol 9: 34-42.

Charalambous M, Shelley AJ, Maia Herzog M, Luna Dias APA 1996. Four new cytotypes of the onchocerciasis vector blackfly Simulium guianense in Brazil. Med Vet Entomol 10: 111-120.

Conn J, Rothfels K, Procunier WS, Hirai M 1989. The Simulium metallicum species complex (Diptera: Simuliidae) in Latin America: a cytological study. Can J Zool 67: 1217-1245.

Coscarón S 1987. El Género Simulium Latrielle en la Región Neotropical: Análisis de los Grupos Supraespécificos, Especies que los Integran y Distribución Geográfica (Simuliidae, Diptera), Museu Paraense Emilio Goeldi, Belém, 112 pp.

Dinardo-Miranda LL 1994. Variabilidade Proteíca em Populações Naturais de Aedes aegypti (Lineaus, 1762) (Diptera, Culicidae), $\mathrm{PhD}$ Thesis, Universidade de São Paulo, Riberão Preto, 122 pp.

Duque S, Muñoz de Hoyos P, Rothfels KH 1988. The polytene chromosomes of Simulium (Ectemnaspis) ignescens Roubaud and related species Simulium "C", both from Colombia. Can J Zool 66: 300-309.

Feraday RM, Leonhardt KG 1989. Absence of population structure in black flies as revealed by enzyme electrophoresis. Genome 32: 531-537.

Hamada N, Adler PH 1999. Cytotaxonomic of four species in the Simulium perflavum species group (Diptera: Silmuliidae). System Entomol 24: 273-288.

Heed WB, Russell JS 1971. Phylogeny and population structure in island and continental species of the Cardini group of Drosophila studied by inversion analysis. Univ Tex Publ 7103: 91-130.

Henderson CA 1986. Homosequential species 2a and 2b within the Prosimulium onychodactylum complex (Diptera): temporal heterogeneity, linkage dis- equilibrium, and wahlund effect. Can J Zool 64: 859866.

Hirai H, Procunier WS, Ochoa JO, Uemoto K 1994. A cytogenetic analysis of the Simulium ochraceum species complex (Diptera: Simuliidae) in Central America. Genome 37: 36-53.

Kiknadze II, Butler MG, Aimanova KG, Gunderina LI, Cooper JK 1996. Geographic variation in the polytene chromosome banding pattern of the Holarctic midge Chironomus (Camptochironomus) tentans (Fabricius). Can J Zool 74: 171-191.

Klein TW 1974. Heritability and genetic correlation: statistical power, population comparisons and sample size. Behav Genet 4: 171-189.

Leonhardt KG 1985. A cytological study of sibling species in the Eusimulium aureum group (Diptera: Simuliidae). Can J Zool 63: 2043-2061.

Leonhardt KG, Feraday RM 1989. Sex chromosome evolution and population differentiation in the Eusimulium aureum group of black flies. Genome 32: 543-549.

Palmer RW, Edwardes M, Nevill EM 1996. Downstream carry of larvicides used in the control of pest black flies (Diptera: Simuliidae) in the Orange river, South Africa. J Vect Ecol 21: 37-47.

Post R 1986. The cytotaxonomy of Simulium sanctipauli and Simulium soubrense (Diptera: Simuliidae). Genetica 69: 191-207.

Procunier WS 1989. Cytological approaches to simuliid biosystematics in relation to the epidemiology and control of human onchocerciasis. Genome 32: 559569.

Rodrigues CS, Kaushik NK 1984. The effect of the temperature on the toxicity of temephos to black fly (Diptera: Simuliidae) larvae. Can Entomol 116: 451455.

Rothfels KH 1979. Cytotaxonomy of black flies (Simuliidae). Ann Rev Entomol 24: 507-539.

Rothfels KH 1980. Chromosomal variability and speciation in blackflies. In RL Blackman, GM Hewitt, M Ashburner (eds), Insect Cytogenetics, Blackwell Scientific Publications, Oxford, p. 207-224.

Rothfels KH, Featherston D 1981. The population structure of Simulium vittatum (Zett.): the IIIL-1 and IS7 sibling species. Can J Zool 59: 1857-1883.

Storfer A 1996. Quantitative genetics: a promising aproach for the assessment of genetic variation in endargered species. TREE 11: 343-348.

Weber EA, Grunewald J 1989. Cytotaxonomic differentiation of Wilhelmia equina (Linné, 1747) and Wilhelmia lineata (Meigen, 1804). Genome 32: 589595.

White MJD 1977. Os Cromossomos, Edusp, São Paulo, $196 \mathrm{pp}$.

Yan G, Chadee DD, Severson DW 1998. Evidence for genetic hitchhiking effect associated with insecticide resistance in Aedes aegypti. Genetics 148: 793-800. 